\title{
HYPOGLYCAEMIC EFFECT OF SAPONIN FROM THE ROOT OF GARCINIA KOLA (BITTER KOLA) ON ALLOXAN-INDUCED DIABETIC RATS
}

\author{
Alli Smith YR*, Adanlawo IG \\ Department of Biochemistry, Ekiti State University, Ado Ekiti, Ekiti State, NIGERIA \\ *Corresponding Author's: Email address: allismithyemisi@yahoo.com
}

Received 30 Sep 2012; Review Completed 09 Nov 2012; Accepted 11 Nov 2012, Available online 15 Nov 2012

\begin{abstract}
Garcinia kola Heckel is a species of flowering plant in the Guttiferae family. The plant has been reffered to as a 'wonder plant' because every part of it has been found to be of medicinal importance. In this present study, saponin extract from the root of Garcinia kola was evaluated for antidiabetic activity in Wistar albino rats. Diabetes was induced in rats by single intraperitonial injection of alloxan $(150 \mathrm{mg} / \mathrm{kg}$ body weight). Three days after alloxan induction, the hyperglycemic rats were treated with metformin, a standard antidiabetic drug and saponin from the root of Garcinia kola orally at the dose of 100, 200 and $400 \mathrm{mg} / \mathrm{kg}$ body weight daily for 7 days. The fasting blood glucose levels were measured on the $3^{\text {rd }}$ and $7^{\text {th }}$ day during the 7 days treatment. Serum biochemical parameters such as Alanine Transaminase (ALT), Aspartate Transaminase (AST), Alkaline Phosphatase (ALP), and total protein were estimated. The saponin extract at the dose of $100 \mathrm{mg} / \mathrm{kg}$ produced the maximum reduction of $35.98 \%$ in blood glucose after the $3^{\text {rd }}$ day treatment as compared to the $31.26 \%$ observed for metformin. $200 \mathrm{mg} / \mathrm{kg}$ dose of saponin produced a maximum reduction of about $72.67 \%$ after the $7^{\text {th }}$ day treatment as compared to $35.84 \%$ observed for metformin. The present study infers that saponin extract from the root of Garcinia kola demonstrated remarkable antidiabetic activity even more than a standard antidiabetic drug in alloxan-induced diabetic rats. Consequently, this plant may be of value in diabetes treatment.
\end{abstract}

Key words: Antidiabetic, Saponin, Garcinia kola, Alloxan.

\section{INTRODUCTION}

Diabetes mellitus is a major illness of the human race implicated with numerous clinical manifestations. It is a clinical syndrome characterized by chronic hyperglycemia with aberration in carbohydrate, fat and protein metabolism resulting from defects in insulin secretion, insulin action or both. It has been reported that the chronic hyperglycemia of diabetes is associated with complications like renal failure, coronary artery disorder, neurological complications, cerebro-vascular disease, blindness, and limb amputation, long term dysfunctions and failure of various organs and eventually premature death. ${ }^{1}$ According to World Health Organization projections, the diabetes population is likely to increase to 300 million or more by the year 2025.,3

High cost of conventional drugs, relatively high incidence of toxicity and side effects, unavailability of orthodox drugs in many rural areas and clinical limitation especially in the management of some chronic diseases are some of the risks in case of modern medicine. Thus, the management of diabetes without any side effect is still a major challenge.

According to the World Health Organization (WHO), approximately $80 \%$ of the world's population currently uses herbal medicines in healing different ailments. Among the estimated 400,000 plant species, only 6\% have been studied for biological activity, and about $15 \%$ have been investigated phytochemically. ${ }^{4,5}$ This shows a need for planned activity guided phyto-pharmacological evaluation of herbal drugs.
Garcinia kola is a species of flowering plant in the Clusiaceae or Guttiferae family. Its natural habitat is subtropical or tropical moist lowland forests. ${ }^{6}$ It has been proved to be one of the many non-timber forest products that are of high socio-economic importance. ${ }^{7}$

Saponins are glycosides with distinctive foaming characteristic. They are widely distributed plant metabolites consisting of a steroidal or a triterpenoid moiety having one or more carbohydrates side chains. Saponins have been reported to possess a wide range of biological activities. This article is aimed at evaluating the antidiabetic potential of saponin extracts of roots of Garcinia kola in alloxan induced diabetic rats.

\section{MATERIALS AND METHODS}

\section{Chemicals and reagents}

Alloxan monohydrate was obtained from Sigma-Aldrich Chemical Co., St. Louis, MO, USA. All other reagents and chemicals used were of analytical grade and were products of Randox Laboratories (Ltd), Atim, U.K and British Drug house limited, Poole, U.K respectively. They were prepared in volumetric flasks and for use.

\section{Plant Materials}

The root of Garcinia kola (Bitter kola) was collected from Ayetoro-Ekiti , Ekiti state, Nigeria. The samples were thoroughly examined to ensure that they were diseases free before they were identified by $\mathrm{Mr}$ Omotayo Oluwafemi at the Herbarium section of Plant Science and Forestry Department, Ekiti State University, Ado- 
Ekiti, Nigeria. A voucher specimen was deposited in the Departmental Herbarium. The roots were cut into bits and air-dried at room temperature; the dried roots were then crushed into coarse Powder with a pestle and mortar and further milled into a fine power using an electric grinding machine.

\section{Preparation of Saponin Extract}

$100 \mathrm{~g}$ of the ground sample was extracted with $500 \mathrm{ml}$ of petroleum ether $\left(40-60^{\circ} \mathrm{C}\right)$ in a soxhlet extractor for $12 \mathrm{~h}$. The air-dried defatted sample was similarly extracted with methanol $(600 \mathrm{ml})$ for $13 \mathrm{~h}$. The method of ${ }^{8}$ was used to purify the saponin from the methanolic extract. This was partitioned between 1:1 (v/v) mixtures of $\mathrm{n}$ - butanol and water. After shaking very well and allowing to stand, the n-butanol layer was separated as a brownish green layer. The aqueous layer was washed with n-butanol until it became colourless. The pooled butanolic layer was evaporated in vacuo to give a residue which was dissolved in $100 \mathrm{ml}$ of methanol and precipitated by adding a large amount of diethyl ether to obtain a solid crystalline dark brown saponin compound. ${ }^{9}$

\section{Animals}

Adult male albino rats $(200-250 \mathrm{~g})$ were obtained from the Animal House of the University of Ibadan, Nigeria. The animals were maintained in a well ventilated room under $12 \mathrm{~h}$ light: $12 \mathrm{~h}$ dark cycle and were acclimatized for 2 weeks before the start of the experiment. Animals were allowed to freely feed on their standard pellet diet and water ad libitum. All the experimental procedures utilized were performed in accordance with the approval of the Institutional Animal Ethics Committee.

\section{Induction of experimental diabetes mellitus}

The animals were fasted for 16-18 hours with free access to water prior to the induction of diabetes. Induction of diabetes was carried out by single intraperitoneal injection of Alloxan Monohydrate (Sigma St Louis, M.O., USA) dissolved in $0.9 \% \mathrm{~V} / \mathrm{V}$ cold normal saline solution at a dose of $150 \mathrm{mg} / \mathrm{kg}$ body weight ${ }^{10}$. The diabetes was assessed in alloxan induced rats by determining the blood glucose concentration 72 hours after injection of alloxan. The diabetic rats were then selected for the study.

\section{Experimental design}

The albino rats were randomly assigned five groups (A-E) of five rats $(n=5)$ each as follows:

Group A-was used as the normal control group and were given only water

Group B- induced with $(150 \mathrm{mg} / \mathrm{kg}$ alloxan) and treated with metformin $(200 \mathrm{mg} / \mathrm{kg}$ body weight)

Group C-induced with $(150 \mathrm{mg} / \mathrm{kg}$ alloxan) and treated with $100 \mathrm{mg} / \mathrm{kg}$ of body weight of the Saponin extract

Group D-induced with $(150 \mathrm{mg} / \mathrm{kg}$ alloxan) and treated with $200 \mathrm{mg} / \mathrm{kg}$ of body weight of the Saponin extract

Group E- induced with $(150 \mathrm{mg} / \mathrm{kg}$ alloxan) and treated with $400 \mathrm{mg} / \mathrm{kg}$ of body weight of the Saponin extract

\section{Determination of blood glucose levels}

The blood samples were collected by cutting the tail artery of the rats. Blood samples for blood glucose determination were collected from the tail at intervals of 0,3 and 7 respectively. Determination of the blood glucose level was done by the glucose oxidase principle ${ }^{11}$ using the one touch glucometer strips and reported in $\mathrm{mg} / \mathrm{dl}$.

\section{Statistical Analysis}

All the data are expressed as mean \pm SEM. Statistical comparisons were performed by one way analysis of variance (ANOVA) followed by Duncan's multiple range tests. $^{12}$ The results were considered statistically significant if the $\mathrm{p}$ values were less than 0.05 . The data were analyzed using SPSS vision 17.0.

\section{RESULTS}

Table 1: The effect of saponin and metformin on blood glucose concentration $(\mathrm{mg} / \mathrm{dl})$ of albino rats after 3 days treatment

\begin{tabular}{|l|l|l|}
\hline TREATMENT & \multicolumn{1}{|c|}{ DAY 0 } & DAY 3 \\
\hline GROUP A (NORMAL SALINE) & $68.00 \pm 5.66^{\mathrm{a}}$ & $62.00 \pm 5.14^{\mathrm{a}}$ \\
\hline GROUP B(METFORMIN 200mg/kg) & $537.50 \pm 86.97^{\mathrm{b}}$ & $369.50 \pm 37.48^{\mathrm{b}}$ \\
\hline GROUP C (SAPONIN 100mg/kg) & $510.00 \pm 25.87^{\mathrm{b}}$ & $326.50 \pm 53.03^{\mathrm{b}}$ \\
\hline GROUP D (SAPONIN 200mg/kg) & $563.00 \pm 50.20^{\mathrm{c}}$ & $495.00 \pm 45.66^{\mathrm{c}}$ \\
\hline GROUP E (SAPONIN 400mg/kg) & $537.00 \pm 66.46^{\mathrm{c}}$ & $518.00 \pm 38.18^{\mathrm{c}}$ \\
\hline
\end{tabular}

Values are expressed as means \pm SEM in ( $\mathrm{mg} / \mathrm{dl})$ means with the same superscript along the same column are not significantly different (P $<0.05)$.

Table 2: The effect of saponin and metformin on blood glucose concentration $(\mathrm{mg} / \mathrm{dl})$ of albino rats after 7 days treatment

\begin{tabular}{|l|l|l|}
\hline TREATMENT & DAY 0 & DAY 3 \\
\hline GROUP A (NORMAL SALINE) & $60.50 \pm 2.51^{\mathrm{a}}$ & $61.50 \pm 2.12^{\mathrm{a}}$ \\
\hline GROUP B(METFORMIN 200mg/kg) & $185.50 \pm 50.20^{\mathrm{b}}$ & $119.00 \pm 31.11^{\mathrm{b}}$ \\
\hline GROUP C (SAPONIN 100mg/kg) & $356.00 \pm 24.42^{\mathrm{b}}$ & $242.50 \pm 21.08^{\mathrm{b}}$ \\
\hline GROUP D (SAPONIN 200mg/kg) & $375.00 \pm 11.31^{\mathrm{b}}$ & $102.50 \pm 68.59^{\mathrm{b}}$ \\
\hline GROUP E (SAPONIN 400mg/kg) & $409.00 \pm 71.12^{\mathrm{c}}$ & $358.00 \pm 79.20^{\mathrm{c}}$ \\
\hline
\end{tabular}


Table 3: The effect of saponin and metformin on some enzyme activity $(\mathrm{u} / \mathrm{l})$ in the serum of albino rats

\begin{tabular}{|l|l|l|l|}
\hline \multicolumn{1}{|c|}{ TREATMENT } & \multicolumn{1}{c|}{ ALT } & \multicolumn{1}{c|}{ AST } & \multicolumn{1}{c|}{ ALP } \\
\hline GROUP A (NORMAL SALINE) & $120.00 \pm 4.00^{\mathrm{a}}$ & $340.00 \pm 10.50^{\mathrm{a}}$ & $73.00 \pm 8.06^{\mathrm{a}}$ \\
\hline GROUP B(METFORMIN 200mg/kg) & $80.00 \pm 2.00^{\mathrm{c}}$ & $402.50 \pm 67.50^{\mathrm{b}}$ & $188.20 \pm 6.50^{\mathrm{b}}$ \\
\hline GROUP C (SAPONIN 100mg/kg) & $120.00 \pm 5.00^{\mathrm{a}}$ & $415.00 \pm 55.00^{\mathrm{b}}$ & $271.90 \pm 16.10^{\mathrm{b}}$ \\
\hline GROUP D (SAPONIN 200mg/kg) & $160.00 \pm 0.00^{\mathrm{b}}$ & $315.00 \pm 20.06^{\mathrm{c}}$ & $352.50 \pm 9.52^{\mathrm{b}}$ \\
\hline GROUP E (SAPONIN 400mg/kg) & $120.40 \pm 6.46^{\mathrm{a}}$ & $385.00 \pm 25.18^{\mathrm{b}}$ & $546.20 \pm 5.10^{\mathrm{b}}$ \\
\hline
\end{tabular}

Values are expressed as means $\pm S E M$ in $(\mathrm{mg} / \mathrm{dl})$ means with the same superscript along the same column are not significantly different $(P<0.05)$.

Table 4: The effect of saponin and metformin on total protein $(\mathrm{g} / \mathrm{l})$ in the tissues of albino rats

\begin{tabular}{|c|c|c|c|c|}
\hline & SERUM & LIVER & KIDNEY & HEART \\
\hline GROUP A & $64.70 \pm 5.94^{\mathrm{a}}$ & $51.19 \pm 1.05^{\mathrm{a}}$ & $41.79 \pm 5.90^{\mathrm{a}}$ & $30.30 \pm 1.48^{\mathrm{a}}$ \\
\hline GROUP B & $64.80 \pm 2.97^{\mathrm{b}}$ & $47.01 \pm 5.22^{\mathrm{c}}$ & $76.26 \pm 10.34^{\mathrm{b}}$ & $45.29 \pm 9.72^{\mathrm{b}}$ \\
\hline GROUP C & $74.20 \pm 13.29^{\mathrm{b}}$ & $50.19 \pm 8.40^{\mathrm{a}}$ & $56.42 \pm 8.88^{\mathrm{b}}$ & $28.21 \pm 4.43^{\mathrm{c}}$ \\
\hline GROUP D & $66.90 \pm 0.00^{\mathrm{b}}$ & $42.84 \pm 1.48^{\mathrm{a}}$ & $54.32 \pm 2.96^{\mathrm{b}}$ & $30.50 \pm 1.56^{\mathrm{a}}$ \\
\hline GROUP E & $62.70 \pm 0.00^{\mathrm{a}}$ & $66.89 \pm 16.7^{\mathrm{b}}$ & $42.84 \pm 1.48^{\mathrm{a}}$ & $34.48 \pm 4.43^{\mathrm{b}}$ \\
\hline
\end{tabular}

Values are expressed as means \pm SEM in ( $\mathrm{mg} / \mathrm{dl})$ means with the same superscript along the same column are not significantly different (P<0.05).

\section{DISCUSSION}

Diabetes is a metabolic disorder which can be considered as a major cause of high economic loss which can in turn impede the development of nations. ${ }^{13}$ Moreover, uncontrolled diabetes leads to many chronic complications such as blindness, heart failure, and renal failure. In order to prevent this alarming health problem, the development of research into new hypoglycaemic and potentially antidiabetic agents is of great interest. Despite the presence of known anti diabetic medicines in the pharmaceutical market, screening for new anti diabetic sources from natural plants is still attractive because they contain substances that have an alternative and safe effect on diabetes mellitus. ${ }^{14}$

In the present study, diabetes was induced in rats by injecting alloxan $(150 \mathrm{mg} / \mathrm{kg}$ BW) i.p. Alloxan is a cytotoxic agent induced diabetes in a wide variety of animal species by damaging insulin secreting $\beta$-cell, resulting in decrease of endogenous insulin release, which paved the way for the decrease utilization of glucose by the tissues which leads to increases blood glucose level. ${ }^{15}$ The findings of this study indicate that administration of saponin in alloxan-induced diabetic rats caused a significant $(\mathrm{P}<0.05)$ antihyperglycemic effect. The saponin extracted from the root of Garcinia kola root led to a decrease of about $35.98 \%$ in blood glucose as against $31.26 \%$ for metformin after 3 days treatment. Saponin also shows a $72.67 \%$ decrease as against the $35.85 \%$ for

\section{REFFERENCES}

[1] Lyra RM; Oliveira D; Lins N; Cavalcanti N., Arquivos Brasileiros de Endocrinol Metabol,2006, 50, 239-249.

[2] Tielmans A, Laloi-Michelin M, Coupaye M, Virally M, Meas $\mathrm{T}$, Guillausseau $\mathrm{P}$, . Traitement médicamenteux du diabète de type 2 (première partie). Presse Med,2007,36: 269-278.

[3] British Medical Association, Board of Science and Education. Diabetes mellitus an update for healthcare professionals. London:BMA Publications Unit; 2004. [On line]Available

http://www.bma.org.uk/images/diabetes_tcm41-20213.pdf. metformin after 7days treatment. The capacity of saponin extracted from the root of Garcinia kola root to significantly decrease elevated blood glucose levels to almost normal levels is an essential trigger for the liver to return to its normal homeostasis in experimental diabetic rats. Moreover, this fact indirectly indicates that the antidiabetic effect of saponin from the root of Garcinia kola is partly due to insulin release from the existing cells of the pancreas. Gymnemic acid, a saponin isolated from Gymnema sylvestre exhibit potent hypoglycaemic activity in animal models, including stimulation of insulin, secretion and release, regeneration of beta cells of Langerhans islets, activation of enzymes responsible for glucose utilization. ${ }^{16}$

\section{CONCLUSION}

This study supports that saponin extract of the root of Garcinia kola possesses antidiabetic properties. The root of this plant seems to have a promising value for the development of potent phytomedicine for diabetes. Further pharmacological and biochemical investigations are required to elucidate its mechanism of action

\section{ACKNOWLEDGEMENTS}

We thank Ekiti State University for the material support to carry out this study. We also appreciate the Staff of Biochemistry Laboratory, Ekiti State University for their technical support

[4]. Srinivasan K, Plant foods in the management of diabetes mellitus:spices as beneficial antidiabetic food adjuncts. Int J Food Sci Nutr,2005, 56(6): 399-414.

[5]. Cragg GM, Newman DJ, Sander KM, Natural products in drug discovery and development, 1997, . 60: 52- 60

[6]. Richards AJ.,Studies in Garcinia, dioecious tropical forest trees. Agamospermy Botanical J. Linnean Soc, 1990, 10(3): 233-250

[7]. Adebisi AA., A Case Study of Garcinia kola Nut Production- to-Consumption System in J4 area of Omo Forest Reserve, South -West Nigeria. In: Forest Products, Livelihoods and Conservation: Case Studies on Non-Timber Forest System, 
Sunderland, T. and O. Ndoye(Eds). CIFOR,Bogor, Indonesia,2004, Vol.2, pp:1-24.

[8]. Kitagawa I, Saito M, Yoshihawa M., Structure of soyaponin A, a bisdesmoside of soya sapogenol A from soyabean, the seeds of Glycine max Merril. Chemical and Pharmaceutical Bulletin,1985, 33: 1069-1072.

[9]. Khalil AH, El-Adawy TA, Isolation, Identification and toxicity of Saponin from different legumes. Food Chemistry, 1994, 50: 197-201.

[10]. Katsumat KY, Katsumat TO, Katsumat K, Horm Metab Res, 1999, 25: 125-126.

[11]. Beach EF, Turner JJ, Clin. Chem.1958, 4: 462-465.

[12]. Duncan RC, Knapp RG, Miller MC, Test of hypothesis in population Means.In: Introductory Biostatistics for the health sciences. John Wiley and Sons Inc. NY,1977, 71-96.
[13]. Mahabir D, Gulliford MC, Use of medicinal plants for diabetes in Trinidad and Tobago. Rev Panam Salud Publica.1997, 1: 174-179.

[14].Jung Bong Ju, Ji. Su kim, Chang Won Choi, Hae Kynug Lee, Tae-Kyun Oh and Sei Chang Kim,Comparison between ethanolic and aqueous extract from Chines Juniper berries for hypoglycaemic effects in alloxan induced diabetic rats. Journal of Ethnopharmacology. 2008,115: 110-115.

[15]. Lenzen S, The mechanism of alloxan and streptozotocininduced diabetes. Diabetologia, 2008, 51:216-226.

[16]. Spasov AA, Maxeiner MP., Bulanov AE, Antidiabetic properties of Gymnema sylvestre. Pharma. Chem. J, 2008,42(11): 626-629. 